Arq. Bras. Med. Vet. Zootec., v.73, n.2, p.277-284, 2021

\title{
Antibodies against Leptospira spp. in bovine serum samples from several Brazilian states analyzed in the period from 2007 to 2015
}

\author{
[Anticorpos contra Leptospira spp. em amostra de soro bovino de diversos estados \\ brasileiros analisados no período entre 2007 e 2015] \\ M.E.C. Furquim, R.F. Santos, L.A. Mathias \\ Faculdade de Ciências Agrárias e Veterinárias - Universidade Estadual Paulista - Jaboticabal, SP
}

\begin{abstract}
Bovine leptospirosis assumes great economic importance since it affects several production aspects. Therefore, knowledge about the occurrence and distribution of this disease is fundamental to adopt the correct prevention measures. The present study aimed to evaluate the frequency of anti-Leptospira spp. antibodies in 24,483 bovine serum samples received between 2007 to 2015 from 21 Brazilian states. Of these, 8,643 (35.3\%) were reagents in the microscopic agglutination test to one or more serovars of Leptospira spp. The most frequent serovars were Wolffi $(61.47 \%)$, Tarassovi $(9.62 \%)$ and Pomona (7.20\%). Hardjo serovar presented a prevalence of $6.27 \%$. Among the 21 states analyzed, the State of Pernambuco had the highest frequency with $88.24 \%$ and the State of São Paulo was the origin of the largest number of analyzed samples $(13,838)$, with a frequency of $31.54 \%$ of reagents. The results demonstrate a high exposure to several serovars of Leptospira spp. in bovine species in Brazilian states, showing the importance of adopting prophylactic measures in order to reduce the risk of infection in this specie.
\end{abstract}

Keywords: epidemiology, leptospirosis, Microscopic Agglutination Test (MAT), vaccination

\section{RESUMO}

Com o objetivo de avaliar a frequência de anticorpos anti-Leptospira spp., foram analisadas 24.483 amostras de soro sanguíneo bovino, provenientes de 21 estados brasileiros, recebidas no período de 2007 a 2015. Destas, 8.643 (35,3\%) foram reagentes no teste de soroaglutinação microscópica a uma ou mais sorovariedades de Leptospira spp., e as sorovariedades com maior frequência foram Wolffi $(61,47 \%)$, Tarassovi (9,62\%) e Pomona (7,20\%). A sorovariedade Hardjo apresentou prevalência de 6,27\%. Entre os 21 estados analisados, o estado de Pernambuco apresentou a maior frequência, com 88,24\%, e o estado de São Paulo foi a origem do maior número de amostras para análise, 13.838, com frequência de 31,54\% de reagentes.

Palavras-chave: leptospirose, teste de soroaglutinação microscópica (MAT), epidemiologia, vacinação

\section{INTRODUCTION}

Leptospirosis is a zoonosis reported all over the world in all animal species already studied and has a great impact in all sectors of cattle production systems, since it is responsible for reproductive failures such as abortions, stillbirths, weak newborns and decrease growth rate (Lilenbaum; Martins, 2014). In dairy herds, the disease is responsible for decreasing milk production, which results in expressive economic loss (Bennett, 2003).

The causative agent of this disease belongs to the genus Leptospira with more than 260 serovars identified, which can be distinguished and grouped into their antigenicity, as well as presents a predilection for its animal host, denominated as maintenance host. However, this bacteria can infect other animal species (accidental hosts) (Levett, 2001; Adler; De La Peña Moctezuma,

Recebido em 12 de agosto de 2020 
2010). Bovine species are the maintenance hosts of Hardjo serovar, which has two serologically indistinguishable types that can be genetically identified: Leptospira interrogans serovar Hardjo (type Hardjoprajitno) and Leptospira borgpetersenii serovar Hardjo (type Hardjobovis) (Bolin, 2003).

In Brazil, the presence of anti-Leptospira agglutinins has been reported in all states, always with high prevalence rates, both at the individual and herds levels (Nicolino et al., 2014). The presence of serogroups such as Wolffi, Icterohaemorragiae, Tarassovi, Pomona and Grippotyphosa in bovine herds is observed, although Hardjo serovar is the most common (Juliano et al., 2000; Favero et al., 2001; Araújo et al., 2005; Castro et al., 2008; Oliveira et al., 2009).

The implementations of leptospirosis control programs in properties must be planned according to the determined purpose, i.e. the control of clinical disease or creation of an immune population (Ellis, 2015). In this sense, a relevant factor for the implementation of any control or even eradication program for leptospirosis is related to the determination of the serovars present in the herd. The balance of the epidemiological triad, composed of environment, host and agent, may be altered over time both by intrinsic and extrinsic factors. Thus, prevalent serovars may change, which justifies the need for periodic diagnostic testing. Considering the importance of knowing the serovars present in the Brazilian bovine population, the present study aimed to evaluate the frequency of antiLeptospira agglutinins in microscopic agglutination tests (MAT) for the diagnosis of bovine leptospirosis carried out between 2007 and 2015.

\section{MATERIAL AND METHODS}

Data were collected from the results of microscopic agglutination tests (MAT) of bovine serum samples that were tested between 2007 and 2015 as part of the Leptospirosis and Brucellosis Diagnostic Laboratory routine. The parameters considered were city origin, animal species, sex and MAT results (titers and interpretation). The Leptospira spp. Antigens used in serological tests were obtained from weekly bacteria subculture in liquid EMJH culture medium (Ellighausen, McCullough, Johnson and Harris), with $10 \%$ of the medium volume used to seed cultures that were kept in a bacteriological incubator at $28^{\circ} \mathrm{C} \pm$ $1^{\circ} \mathrm{C}$ (OIE, 2014).

The employed serovars of Leptospira were Australis, Autumnalis, Bratislava, Canicola, Copenhageni, Grippotyphosa, Hardjo, Hebdomadis, Icterohaemorragiae, Patoc, Pomona, Pyrogenes, Tarassovi and Wolffi. The blood serum samples were diluted in saline, at an initial dilution of $1 / 50$. Serum aliquots $(25 \mu \mathrm{L})$ were placed in polystyrene plates with a flat bottom, with an equal quantity of antigens as the 14 serovars of Leptospira spp., resulting in a dilution of $1 / 100$. The serum-antigen mixture was homogenized gently and incubated in an environmental incubator at $28^{\circ} \mathrm{C}$ for 40 to 120 minutes. The results were read by dark field microscopy with 10x lens, directly from the plate wells.

Samples with $50 \%$ agglutination were considered reactive. Samples that were reactive at the initial dilution were assayed with serial, 2-fold dilutions from the original 1/100 dilution, as recommended by OIE (2014). To determine the most probable serovar, we considered only the one with highest titer and disregarded the animals with equal titers against two or more serovars. Frequencies of variables (gender) were compared by chi-square test or Fisher's exact test using the R software ( $\mathrm{R}$ Core Team 2003). The confidence interval (CI) of the observed frequencies was calculated as described by Thrusfield (2005). The thematic map was elaborated using TerraView software (TerraView, 2010).

\section{RESULTS}

A total of 24,483 bovine serum samples were analyzed between 2007 and 2015. Of these, 8,643 were reagents in MAT against one or more serovars of Leptospira spp. (35.30\%, 95\% CI: 34.70 - 35.90). In 2014, 53.84\% (95\% CI: $51.59 \%$ $-55.18 \%$ ) of the samples were positive, this year being the one with the highest frequency of reactive samples. In 2007, $12.55 \%$ (95\% CI: $10.74 \%-14.36 \%$ ) of the samples were positive, being this the year with the lowest frequency of reactive samples. Data for other years are shown in Table 1. 
Table 1. Frequency of bovine serum samples reactive against Leptospira spp. in relation to the year in which they were analyzed in the period from 2007 to 2015

\begin{tabular}{ccccc}
\multirow{2}{*}{ Year } & \multicolumn{2}{c}{ Samples } & \multirow{2}{*}{ Frequency $(\%)$} & CI 95\% $(\%)$ \\
\cline { 2 - 3 } & Analyzed & Reactive & 12.55 & $10.74-14.36$ \\
\hline 2007 & 1,283 & 161 & 22.19 & $20.79-25.58$ \\
2008 & 3,407 & 756 & 32.82 & $31.05-34.58$ \\
2009 & 2,709 & 889 & 24.80 & $23.16-26.43$ \\
2010 & 2,690 & 667 & 38.34 & $36.65-40.05$ \\
2011 & 3,145 & 1,206 & 30.91 & $29.06-32.76$ \\
2012 & 2,391 & 739 & 42.29 & $40.80-43.78$ \\
2013 & 4,235 & 1,791 & 53.84 & $51.59-55.18$ \\
2014 & 2,969 & 1,585 & 51.33 & $48.92-53.74$ \\
2015 & 1,654 & 849 & 35.30 & $34.70-35.90$ \\
Total & 24,483 & 8,643 & & \\
\hline
\end{tabular}

CI: Confidence interval

The samples titers ranged from 100 to 1,600 for the 14 serovars used in the serological diagnostic test. The titer 200 was the most frequent, observed in $2,610(38.2 \%)$ of the reactive samples, followed by titer 100 with $2,254(33 \%)$ of the reactive samples. The most frequent serovars were Wolffi with $61.47 \%(4,198)$, Tarassovi with $9.62 \%$ and Pomona with $7.20 \%$ (Table 2). Only 15,017
(61.34\%) of the samples had information on the animals' sex. Of these, 10,692 (71.20\%) were females and 4,325 (28.80\%) were males. The frequency found in female animals was $37.53 \%$ and $28.39 \%$ in males (Table 3). A significant difference was observed between these proportions $(\mathrm{P}<0.001)$.

Table 2. Number of reactions according to the agglutinin's titer against serovars used in the microscopic agglutination test for bovine leptospirosis diagnosis in 8,643 seroreagent samples between 2007 and 2015

\begin{tabular}{|c|c|c|c|c|c|c|c|}
\hline \multirow{2}{*}{ Sorovars } & \multicolumn{5}{|c|}{ Titer } & \multicolumn{2}{|c|}{ Total } \\
\hline & 100 & 200 & 400 & 800 & 1600 & $\mathrm{~N}$ & $\%$ \\
\hline Australis & 1 & - & - & - & - & 1 & 0.01 \\
\hline Autumnalis & 1 & 1 & 1 & - & - & 3 & 0.04 \\
\hline Bratislava & 1 & - & - & - & - & 1 & 0.01 \\
\hline Canicola & 23 & 25 & 12 & 9 & - & 69 & 1.01 \\
\hline Copenhageni & 52 & 44 & 13 & 24 & - & 133 & 1.95 \\
\hline Grippotyphosa & 139 & 215 & 50 & 85 & - & 489 & 7.16 \\
\hline Hardjo & 199 & 152 & 38 & 38 & 1 & 428 & 6.27 \\
\hline Hebdomadis & 7 & 1 & - & 1 & - & 9 & 0.13 \\
\hline Icterohaemorragiae & 154 & 134 & 46 & 12 & - & 346 & 5.07 \\
\hline Patoc & 1 & - & 1 & - & - & 2 & 0.03 \\
\hline Pomona & 129 & 180 & 75 & 108 & - & 492 & 7.20 \\
\hline Pyrogenes & 1 & - & - & - & - & 1 & 0.01 \\
\hline Tarassovi & 234 & 282 & 78 & 63 & - & 657 & 9.62 \\
\hline Wolffi & 1.312 & 1.576 & 515 & 794 & 1 & 4,198 & 6.47 \\
\hline Total & $\begin{array}{l}2,254 \\
(33 \%)\end{array}$ & $\begin{array}{c}2,610 \\
(38.2 \%) \\
\end{array}$ & $\begin{array}{c}829 \\
(12.1 \%)\end{array}$ & $\begin{array}{c}1,134 \\
(16.6 \%)\end{array}$ & $\begin{array}{c}2 \\
(0.03 \%)\end{array}$ & 6,829 & 100.00 \\
\hline
\end{tabular}

$\mathrm{N}$ : number of positive animal samples for each agglutinin titer.

$\%$ : percentage of positive animal samples for each agglutinin titer in relation to the total positive animal samples.

Table 3. Frequency of bovine reactive samples in the microscopic seroagglutination test for the diagnosis of leptospirosis regarding animal's sex in samples analyzed between 2007 and 2015

\begin{tabular}{ccccccc} 
& Analyzed & Reactive & Frequency $(\%)$ & CI 95\% (\%) & $\mathrm{X}^{2}$ & P Value \\
\hline Female & 10.692 & 4.013 & 37,53 & $36,61-38,45$ & \multirow{2}{*}{112,8157} & $<2,2$ e-16 \\
Male & 4.325 & 1.228 & 28,39 & $27,05-29,74$ & \\
\hline
\end{tabular}


Among the total samples, 680 had no information about the place of origin in their records and $40 \%$ (272 samples) had antibodies against Leptospira. The rest of the samples came from 21 Brazilian states, except for the states of Acre, Amapá, Amazonas, Paraíba, Piauí and Rio Grande do Norte (Figure 1). The frequency of reactive samples per state varied between $88.24 \%(95 \%$ CI: $73.38 \%-95.33 \%$ ) and $6.67 \%$ (95\% CI: $1.19 \%$ $-29.82 \%)$. The state with the highest frequency of reactive samples was Pernambuco with $88.24 \%$ (95\% CI: $73.38 \%$ - 95.33\%). São Paulo state presented the highest number of samples sent for analysis $(13,838$ samples) with $31.54 \%$ of reactive samples (95\% CI: $30.76 \%$ - 32.31\%). Next, there is Minas Gerais, with 3,758 samples sent and a frequency of $33.69 \%$ (95\% CI: 32.18$35.20)$ reactive samples. The other data related to the origin state of the submitted samples are shown in Table 4.

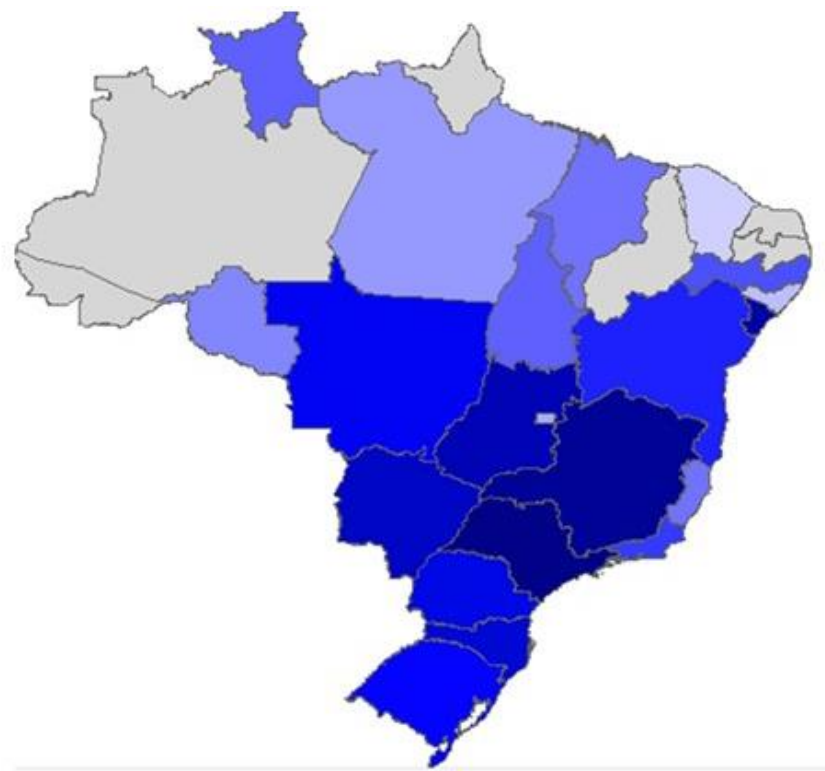

\section{Positive samples}

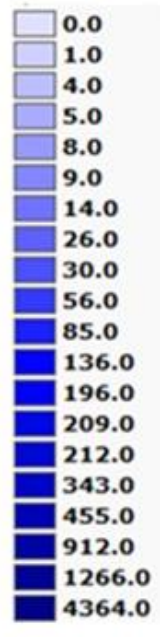

Figure 1. Brazil's map showing the distribution of the reactive samples in the microscopic seroagglutination test for the diagnosis of bovine leptospirosis found during the analyses between 2007 and 2015. The states marked in gray did not send any samples for analysis.

\section{DISCUSSION}

By 2050, it is expected that developing countries will be responsible for $70 \%$ of the world's meat production due to a higher number of animals and mostly by an enhanced productivity, once the agricultural sustainable limits are being reached. Milk production in developing countries have already surpassed the developed ones' (Alexandratos; Bruinsma, 2012). Nevertheless, in Brazil, it has been estimated that approximately $30 \%$ of the cows exhibit reproductive failures (Lilenbaum; Martins, 2014) leading to a productivity decrease. Leptospirosis is considered endemic in national territory and despite its importance, it is still a neglected disease due to the paucity of information on its epidemiological data. With such information, a disease control program could be properly developed in herds through vaccination, antibiotic treatment, removal of infected animals, control of rodents, reduction of management-related risk factors, among others (Ellis, 2015).

The retrospective study of the laboratory data on the detection of agglutinins anti-Leptospira spp. showed that the frequency of reagent samples was $35.30 \%(8.643)$ in the analyzed period. In similar study between 1984 and 1997, a 37,94\% (11,884) frequency of reagents was obtained in the analysis of 31,325 bovine serum samples from 21 Brazilian states (Favero et al., 2001). The State of Pernambuco had the highest frequency of reagents $(88.24 \%)$ among the states studied. Study carried out in the same state, the frequency of reactive animals for leptospirosis found in a bovine herd was $57.7 \%$ (Tenório et al., 2005). The state of São Paulo presented a frequency of $31.54 \%$, and other 
studies conducted in this state the frequencies ranged from $35 \%$ to $49.4 \%$ (Favero et al., 2001; Castro et al., 2008). In Minas Gerais state, the frequency observed for the bovine species in different studies ranged from $21.7 \%$ to $65.20 \%$ (Favero et al., 2001; Nicolino et al., 2014). The present study, the observed frequency for this state was $33.69 \%$.

Table 4. Frequency of bovine reactive samples in the microscopic seroagglutination test for the diagnosis of leptospirosis in relation to the origin state of the samples sent for analysis between 2007 and 2015

\begin{tabular}{lccccc}
\hline \multirow{2}{*}{ States } & \multicolumn{2}{c}{ Samples } & \multirow{2}{*}{ Frequency $(\%)$} & CI 95\% $(\%)$ \\
\cline { 2 - 3 } & Analyzed & Reactive & 4 & 44.44 & $11.98-76.91$ \\
Alagoas & 9 & 4 & 28.91 & $23.73-34.09$ \\
Bahia & 294 & 85 & 6.67 & $1.19-29.82$ \\
Ceará & 15 & 1 & 25.00 & $11.19-46.87$ \\
Distrito Federal & 20 & 5 & 26.92 & $14.87-38.98$ \\
Espírito Santo & 52 & 14 & 45.59 & $42.50-48.68$ \\
Goiás & 998 & 455 & 41.18 & $24.63-57.72$ \\
Maranhão & 34 & 14 & 33.69 & $32.18-35.20$ \\
Minas Gerais & 3,758 & 1,266 & 63.40 & $59.34-67.46$ \\
Mato Grosso do Sul & 541 & 343 & 57.65 & $52.39-62.90$ \\
Mato Grosso & 340 & 196 & 57.14 & $31.22-83.07$ \\
Pará & 14 & 8 & 88.24 & $73.38-95.33$ \\
Pernambuco & 34 & 30 & 33.23 & $29.55-36.91$ \\
Paraná & 629 & 209 & 22.40 & $17.23-27.57$ \\
Rio de Janeiro & 250 & 56 & 69.23 & $42.37-87.32$ \\
Rondônia & 13 & 9 & 61.90 & $47.22-76.59$ \\
Roraima & 42 & 26 & 43.73 & $38.22-49.24$ \\
Rio Grande do Sul & 311 & 136 & 24.75 & $21.85-27.63$ \\
Santa Catarina & 857 & 212 & 53.27 & $50.91-55.63$ \\
Sergipe & 1,712 & 912 & 31.54 & $30.76-32.31$ \\
São Paulo & 13,838 & 4,364 & 61.90 & $47.22-76.59$ \\
Tocantins & 42 & 26 & 35.30 & $34.70-35.90$ \\
Total & 23,803 & 8,371 & & \\
\hline
\end{tabular}

The most frequent titer found in this study was the 200 titer and according to Picardeau (2013), titles of 100 or 200 can indicate the existence of recent or previous infection to the test, as well as the presence of vaccine antibodies. Titers greater than 400 are considered as indicative of current infection, in the presence of clinical and correct animal historical symptoms (Faine et al., 1999). The titers between 100 and 200 found in this study corresponded to $71.20 \%$ of the titers obtained in reagent samples. However, the vaccination data regarding the animals were not shown in the database, making it impossible to infer that such titles were due to vaccination. The titles of 400 , 800 and 1,600 found corresponded to $28.8 \%$ of the titles.

Usually in bovine species the differential diagnosis of leptospirosis is due to clinical suspicion in the presence of reproductive disorders or as part of insemination centers routine. Hardjo serovar is identified as the most frequent in this species, since these animals act as their maintenance host, causing great economic impact due to abortions and the decrease in milk production. However, in this study, Wolffi serovar presented the highest frequency $(61.47 \%)$ among all serovars used in MAT. Similarly, Langoni et al. (2000) found that Wolffi serovars was the most frequent $(70.59 \%)$. in 2,761 bovine serum samples from different regions of the state of SP.

The frequency presented by Hardjo serovar was of $6.27 \%$ among the samples analyzed. In similar works by Araújo et al. (2005), Lage et al. (2007), Oliveira et al. (2009) and Nicolino et al. (2014), the frequencies obtained ranged from $14.95 \%$ to $23.7 \%$. The higher frequency of Wolffi serovar in relation to Hardjo serovar can be attributed to ecological factors resulting from the relation of several Leptospira serovars and animals with the environment in which they live (Faine, 1982). This way, it is possible to imply that over time 
some serovars become more prevalent than others caused by an imbalance in the epidemiological triad.

The serogroups Hardjo and Wolffi belong to the Sejroe serogroup and are antigenically similar, allowing the occurrence of cross-reactions during serological diagnosis, which increases the presence of false-positive results. This was proven by a research which tested serovar specific vaccines of the Sejroe serogroup (Hardjo, Wolffi and Guaricura) and obtained positive MAT results to each serovar tested (Tabata et al., 2002). However, there are no reports on the isolation of Wolffi serovar in Brazilian cattle, unlike Hardjo serovar which was isolated for the first time by Moreira (1994) (Tabata et al., 2002). Vaccination against bovine leptospirosis is currently at the discretion of the owner and the commercial vaccines available normally contains Hardjo, Pomona, Ichterohaemorrhagiae, Canicola and Grippotyphosa serovars. It is also found vaccines that contain others serovars, such as Wolffi and Copenhageni.

The expressive number of samples reactive to serovars Wolffi and Copenhageni with titers higher than 400 raise the question of the vaccination status of the animals sampled, once lower titers of these serovars are expected with vaccination. It is known that several vaccines sold in Brazil are imported and those produced nationally employ reference Leptospira strains that differ from those found in the field. Such vaccines are incapable of inducing a (Sonada et al., 2018)(Sonada et al., 2018) long-term immunity and neither protect from disease or infection nor prevent from the establishment of the renal carrier state (Sonada et al., 2018).

In a study conducted by Tabata et al. (2002), cross-protection between vaccines formulated from Sejroe serogroup antigens was investigated and the vaccine produced with Hardjo serovar was capable to elicit immunological response against Wolffi serovar but was not able to induce protection against its homologous serological variant Hardjo, whereas the vaccine produced from Wolffi serovar induced immunity against both its Wolffi homologous serological variant and against Hardjo serovar. Other study by Arduino et al. (2009), both Wolffi and Hardjo serovars were able to produce cross-immunity to each other.
However, in a study conducted to evaluate the efficacy of commercial vaccines, only two of five tested vaccines were proven to be effective and were able to prevent the real carrier state (Sonada et al., 2018). Only two of the vaccines used in this study had the Wolffi serovar in their formulation and none of the effective vaccines had it, proving that the vaccines found in the market are inefficient to successfully induce immunity against Wolffi serovar. The frequency of reactives to Tarassovi and Pomona serovars was $9.62 \%$ and $7.20 \%$, respectively. Other investigations found that the frequencies of Tarassovi and Pomona ranged from $0.329 \%$ to $3.3 \%$ and $0.54 \%$ to $2.8 \%$, respectively (Araújo et al., 2005; Oliveira et al., 2009; Silva et al., 2011). Such serovars have the porcine species as their maintenance host (Levett, 2001) and breeding these animals separately from the bovine species is ideal to decrease the environmental contamination by these serovars. However, there is a large number of properties that still breed different animal species in the same space.

The knowledge of which Leptospira serovar is found among bovine population as well as the circulating through Brazilian regions is of great importance to establish the best way to prevent infection and vaccination is one of the best tools available to this end, which can hinder the development of renal carrier status and thus, decrease the environmental and herd contamination. Nevertheless, such information is achieved mainly through surveillance campaigns that are scarce in the national territory.

\section{CONCLUSION}

Through this study, it is possible to infer that bovine leptospirosis is a widely disseminated disease in Brazil. The most frequent serovars were Wolffi, Tarassovi and Pomona and the States with the highest frequencies of reactive samples were Pernambuco, Rondonia and Mato Grosso do Sul. Despite the questionable efficiency of the vaccines employed in Brazil, vaccination is still the best way to prevent infection along with surveillance campaigns aiming to increase the knowledge of the circulating serovars to best control this agent. 


\section{ACKNOWLEDGMENTS}

This research did not receive any specific grant from funding agencies in the public, commercial, or not-for-profit sectors.

\section{REFERENCES}

ADLER, B.; DE LA PEÑA MOCTEZUMA, A. Leptospira and leptospirosis. Vet. Microbiol., v.140, p.287-296, 2010.

ALEXANDRATOS, N.; BRUINSMA, J. World Agriculutre Towards 2030 / 2050: the 2012 revision. ESA Working Paper, n.12, p.160, 2012.

ARAÚJO, V.E.M.; MOREIRA, E.C.; NAVEDA, L.A.B.; SILVA, J.A.; CONTRERAS, R.L. Frequiência de aglutininas anti-Leptospira interrogans em soros sangüíneos de bovinos, em Minas Gerais, de 1980 a 2002. Arq. Bras. Med. Vet. Zootec., v.57, p.430-435, 2005.

ARDUINO, G.G.C.; GIRIO, R.J.S.; MAGAJEVSKI, F.S.; PEREIRA, G.T. Títulos de anticorpos aglutinantes induzidos por vacinas comerciais contra leptospirose bovina. Pesqui. Vet. Bras., v.29, p.575-582, 2009.

BENNETT, R. The 'Direct Costs'of livestock disease: the development of a system of models for the analysis of 30 endemic livestock diseases in Great Britain. J. Agricul. Econ., v.54, p.55-71, 2003.

BOLIN, C.A. Diagnosis and control of bovine leptospirosis. In: WESTERN DAIRY MANAGEMENT CONFERENCE, 6., 2003, Reno. Proceedings... Reno: [s.n.], 2003.

CASTRO, V.; AZEVEDO, S.S.; GOTTI, T.B. et al. Idade reprodutiva no estado de São Paulo, BrasiL. Arq. Inst. Biol., v.75, p.3-11, 2008.

ELLIS, W. A. Animal leptospirosis. Curr. Top. Microbiol. Immunol., v.387, p.99-137, 2015.

FAINE S. Guidelines for the control of leptospirosis. 1982. Disponível em: <http://apps.who.int/iris/handle/10665/37219>. Acessado em: 25 de janeiro de 2021.

FAINE S., ADLER B., BOLIN C. et al. Leptospira and Leptospirosis. 2. ed. Australia: Medisci Press, 1999. 272p.
FAVERO, M.; PINHEIRO, S.R.; VASCONCELLOS, S.A. et al. Variantes sorológicas predominantes em colheitas efetuadas no período de 1984 a 1997 em rebanhos de 21 estados do Brasil. Arq. Inst. Biol., v.68, p.29-35, 2001.

JULIANO, R.S.; CHAVES, N.S.T.; SANTOS, C.A. et al. Prevalência e aspectos epidemiológicos da leptospirose bovina em rebanho leiteiro na microrregião de Goiânia - GO. Ciênc. Rural, v.30, p.857-862, 2000.

LAGE, A. P.; LEITE, R. M. H.; THOMPSON, J. A. et al. P. Serology for leptospira sp . in cattle of the state oF Paraíba , Brazil. Arq. Inst. Biol., v.74, p.185-190, 2007.

LANGONI, H.; MEIRELES, L.R.; GOTTSCHALK, S.; CABRAL, K.G.; SILVA, A.V. Perfil sorológico da leptospirose bovina em regiões do Estado de São Paulo. Arq. Inst. Biol., v.67, n.1, 2000.

LEVETT, P.N. Leptospirosis. Clinic. Microbiol. Rev., v.14, p.296-326, 2001.

LILENBAUM, W.; MARTINS, G. Leptospirosis in cattle: a challenging scenario for the understanding of the epidemiology. Transboundary Emerg. Dis., v.61, Suppl.1., p.6368, 2014.

MOREIRA E C. Avaliação de métodos para erradicação de leptospiroses em bovinos leiteiros. 1994. 93f. Tese (Doutorado em Ciência Animal) - Escola de Veterinária, Universidade Federal de Minas Gerais, Belo Horizonte, 1994.

NICOLINO, R.R.; LOPES, L.B.; RODRIGUES, R.O.; TEIXEIRA, J.F.B.; HADDAD, J.P.A. Prevalence and spatial analysis of antileptospiral agglutinins in dairy cattle - Microregion of Sete Lagoas, Minas Gerais, 2009/2010. Arq. Bras. Med. Vet. Zootec., v.66, p.648-654, 2014.

OIE - World Organization for Animal Health. Manual of diagnostic test and vaccines for terrestrial animals. 2014. Disponível em: <https://www.oie.int/fileadmin/Home/eng/Health _standards/tahm/3.01.12_LEPTO.pdf $>$. Acesso em: 25 de janeiro de 2021. 
OLIVEIRA, F.C.S.; AZEVEDO, S.S.; PINHEIRO, S.R. et al. Soroprevalência de leptospirose em fêmeas bovinas em idade reprodutiva no Estado da Bahia. Arq. Inst. Biol., v.76, p.539-546, 2009.

PICARDEAU, M. Diagnosis and epidemiology of leptospirosis. Med. Mal. Infect., v.43, p.1-9, 2013.

R CORE TEAM (2003). R: A language and enviroment for statistical computing. R Foundation for Statistical Computing, Vienna, Austria. Disponível em: <http://R-project.org/>.

SILVA, F. J.; CONCEIÇÃO, W. L. F.; FAGLIARI, J. J. et al. Prevalência e fatores de risco de leptospirose bovina no estado do maranhão. Pesq. Vet. Bras., v. 32, n. 4, p. 303312, 2012.

SONADA, R.B.; AZEVEDO, S.S.; SOTO, F.R.M. et al. A. Efficacy of leptospiral commercial vaccines on the protection against an autochtonous strain recovered in Brazil. Braz. J. Microbiol., v.49, p.347-350, 2018.
TABATA, R.; SCANAVINI NETO, H.; ZUANAZE, M.A.F. et al. Cross neutralizing antibodies in hamsters vaccinated with leptospiral bacterins produced with three serovars of serogroup Sejroe. Braz. J. Microbiol., v.33, p.265-268, 2002.

TENÓRIO, T.G.S.; MELO, L.E.H.; VASCONCELLOS, S.A. et al. Seroprevalence of brucelosis and leptospirosis in dairy bovine herds of Pernambuco State, Brazil. Vet. Notícias, v.11, p.43-48, 2005.

TERRAVIEW 4.1.0. São José dos Campos, SP: INPE, 2010. Disponível em: www.dpi.inpe.br?terraview. Acessado em: 1 out. 2016.

THRUSFIELD, M. Veterinary epidemiology. 3.ed. Oxford: Balckwell Science, 2005. 610p. 